\title{
The Effects of Bike Desks in Formal Education Classroom-Based Physical Activity: A Systematic Review
}

\author{
Beatriz Polo-Recuero ${ }^{1,2, * \mathbb{D}}$, Miguel Ángel Rojo-Tirado ${ }^{3} \mathbb{D}$, Alfonso Ordóñez-Dios ${ }^{4} \mathbb{D}$, Denise Breitkreuz ${ }^{5}$ \\ and Alberto Lorenzo ${ }^{1}$ (D)
}

1 Department of Sports, Faculty of Physical Activity and Sport Sciences, Universidad Politécnica de Madrid, 28040 Madrid, Spain; alberto.lorenzo@upm.es

2 Faculty of Social and Legal Sciences, Universidad Rey Juan Carlos, 28933 Madrid, Spain

3 LFE Research Group, Department of Health and Human Performance, Facultad de Ciencias de la Actividad Física y del Deporte, Universidad Politécnica de Madrid, 28040 Madrid, Spain; ma.rojo@upm.es

4 Department of Physical Education, Sport and Human Motor Skills, Faculty of Teacher Training and Education, Universidad Autónoma de Madrid, 28049 Madrid, Spain; alfonso.ordonnez@estudiante.uam.es

5 Department of Health and Human Performance, Palm Beach Atlantic University, West Palm Beach, FL 33401, USA; denise_breitkreuz@pba.edu

* Correspondence: beatriz.polo.recuero@alumnos.upm.es or beatriz.polo.recuero@urjc.es or bpolo@educa.madrid.org

check for updates

Citation: Polo-Recuero, B.; Rojo-Tirado, M.Á.; Ordóñez-Dios, A.; Breitkreuz, D.; Lorenzo, A. The Effects of Bike Desks in Formal Education Classroom-Based Physical Activity: A Systematic Review. Sustainability 2021, 13, 7326. https:// doi.org/10.3390/su13137326

Academic Editors: Francis Ries, Richard Bailey and Claude Scheuer

Received: 8 June 2021

Accepted: 22 June 2021

Published: 30 June 2021

Publisher's Note: MDPI stays neutral with regard to jurisdictional claims in published maps and institutional affiliations.

Copyright: (c) 2021 by the authors. Licensee MDPI, Basel, Switzerland. This article is an open access article distributed under the terms and conditions of the Creative Commons Attribution (CC BY) license (https:/ / creativecommons.org/licenses/by/ $4.0 /)$.

\begin{abstract}
A systematic review of the research conducted on classroom-based physical activity using bike desks, a school health prevention strategy. To our knowledge, this is the first systematic review of bike desks effects on formal education students. Articles from two databases, Web of Science and PubMed, were analyzed according to PRISMA. The quality of each study was analyzed. After the exclusion criteria, eight articles were fully assessed based on six criteria: (1) author and year, (2) setting and sample, (3) duration, (4) outcomes measurements, (5) instruments and (6) main results. The results show how the interventions are mainly in secondary education and university, and most of them are quantitative studies of short-term interventions. Physical activity is the most frequently variable assessed, using logs, questionnaires and objective methods such as accelerometry and heart rate monitoring. Based on all the studies, it is feasible to implement bike desks in the classroom during theoretical lessons. The weaknesses are related to small samples and the use of different instruments to measure. In conclusion, this systematic review compiles the current information about bike desks in order to inform teachers and administrators for the implementation of bike desk in their schools. They should consider bike desks' strengths and weaknesses.
\end{abstract}

Keywords: physically active learning; active schools; health; adolescents; inactivity; sedentarism

\section{Introduction}

More than $80 \%$ of worldwide adolescent population is insufficiently physically active [1] and more than a quarter of adults do not get enough physical activity [2]. Fortunately, despite the fact that the students of any level spend most of their day seated in a desk, during extracurricular leisure time, students practice different physical activities and sports. However, their activity depends not only on their will but also on the accessibility of its resources. Because school is the place where they spent at least half of their waking day [3], it is the only and ideal place to ensure that every student exercises [4], increasing the amount of physical activity they do [5] and implementing health prevention strategies [6].

Few universities require lifetime fitness/wellness courses for their students [7]. Regarding elementary and secondary schools, physical education is the main subject based on physical activity throughout the world. This important subject entails plenty of physical activity [8], health [9,10], cognitive [11] and academic [12] benefits for the student. However, the time dedicated to physical education is insufficient $[13,14]$ and it does not comply with 
the World Health Organization recommendations to perform at least 60 min of moderate to vigorous intensity physical activity (MVPA) daily, including strength activities three days per week for children and teenagers [15]. Undergraduates are considered adults, hence, they should perform at least $150 \mathrm{~min}$ of MVPA, or 75 min of vigorous intensity physical activity throughout the week [15].

On account of this, schools have sought innovative strategies to increase the level of physical activity during school hours and to reduce sedentary time. Figure 1 summarizes the school physical activity possibilities of the students.

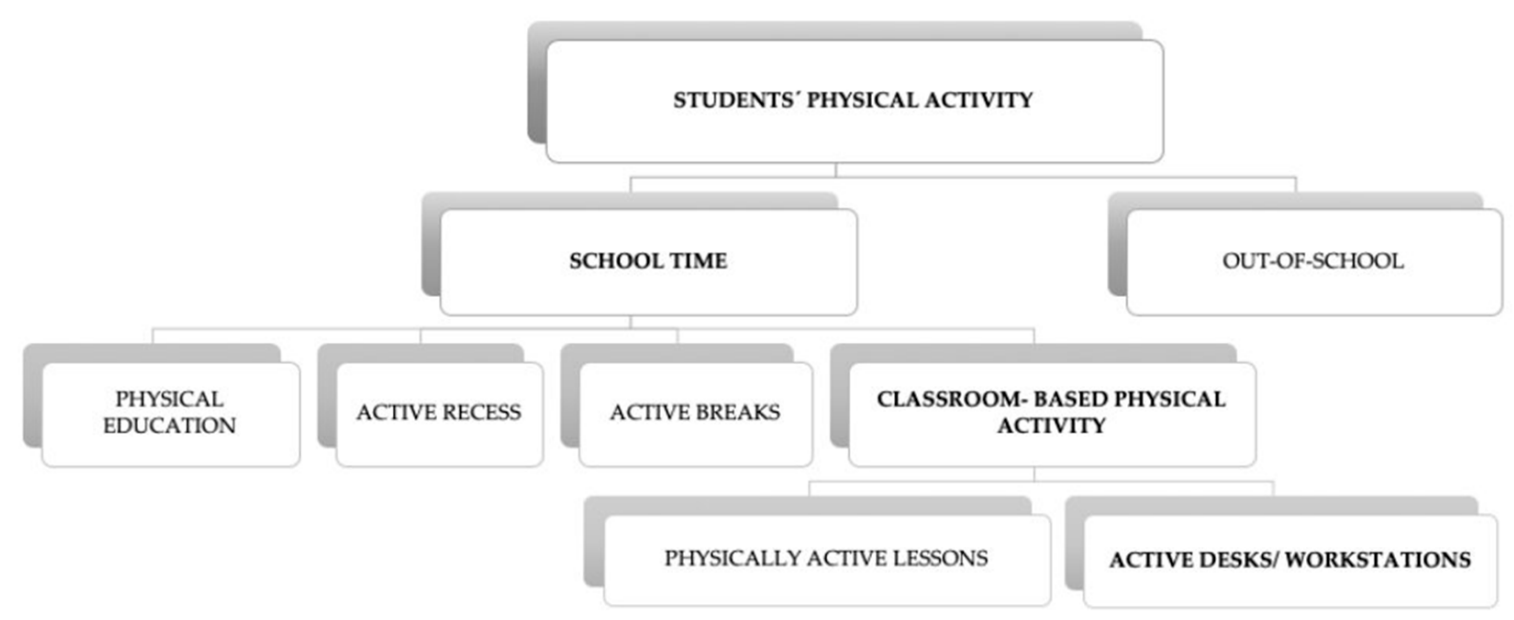

Figure 1. Strategies to increase children's and adolescents' physical activity.

Physically active learning [16] integrates movement into academic activity in two different ways. On the one hand, the physically active lessons, with a modified methodology or active pedagogical strategies, transmit academic content through movement. In order to do this, the teacher modifies the teaching methodology to incorporate movement, either throughout the whole session or just through active academic breaks. These lessons bring positive outcomes, the main one is the increase of the students' physical activity level [17-19], although there is limited evidence that this physical activity is MVPA, which is recommended for its health benefits [20]. In addition, benefits have been found in learning mathematical content [21], concentration and attention [22], fluid intelligence [23], academic performance [24,25], behavior [26,27], cardiorespiratory fitness [28] and enjoyment [29].

On the other hand, classroom-based physical activity could be achieved by establishing kinesthetic classrooms with active desks. These classrooms integrate different physical activity devices, hereinafter known as active desks, in the traditional classroom. The active desks allow students to attend while they are doing physical activity. According to the review [30], active desks are a promising element in schools. They are based on Howard Gardner's multiple intelligences model [31] and combine academic content learning with movement during active lessons. It is remarkable that active desks do not seem to interrupt the classes and it tends to not reduce instruction time, but it requires a financial investment. There are different models of active desks [32-34]. Bike desks consist of a resistance that allows pedaling on site and have been named under different denominations: bike pedal desks/exercisers, bicycle/cycling workstations, stationary bicycle/cycle under the desks.

Bike desks have been satisfactorily implemented in workplaces such as offices [35-37] and libraries [38,39]. Moreover, the devices have been evaluated under laboratory conditions with undergraduates [40,41] and preadolescents [42] with positive effects on learners' affective state and no detriment on academic or cognitive performance.

This paper aims to systematically review the available studies describing bike desks interventions in school, high school or university formal courses. 


\section{Materials and Methods}

The study was carried out based on the PRISMA statement guidelines [43] and registered in the International Prospective Register of Systematic Reviews (PROSPERO) (identifier ID: CRD42020186985).

Bike desks studies in formal education were searched in Web of Science and MEDLINE (via Pubmed). The search was done during May 2020 using the Boolean search method. The search combined the following terms: "bike", "bycicle", "cycle", "pedal", "elliptical", "cycling" combined with either "desk" or "workstation" and combined with either "school", "class" or "student". After the database searching was completed, two papers from additional sources were included.

Research articles were analyzed using the PICOS strategy criteria [44] to find projects or programs in which the students attended their traditional lessons using bike desks. Studies were required to be written in English or Spanish. All of them had to be published in a peer review journal or to be part of a PhD thesis or dissertation. Since bike desks have been recently implemented in school contexts, it was decided to use the publication dates between 2014 and 2020 because back in 2014, a systematic review [32] stated that all the 16 studies found on the use of walking and cycling workstations investigated their use just in adults. Thus, there were no records of students using active desks. The inclusion criteria were (a) the populations included students (elementary, secondary or college), (b) interventions with bike desk in formal learning lessons, (c) study designs carried out in schools and (d) at least physical activity or feasibility outcomes of the intervention should be reported. Working adult populations, non-formal learning contexts and studies conducted in labs were excluded.

The main investigator searched in databases to extract the results, eliminating the duplicates. Then, two investigators autonomously analyzed the articles to check if they met the eligibility criteria. They had a $100 \%$ agreement selecting the papers about formal learning using bike desks. Finally, two researchers reviewed the whole investigation process.

\section{Results}

Figure 2 shows the PRISMA consort flow diagram that describes the search strategy and selection process. A total of 116 manuscripts were identified, of which 68 were duplicates. Subsequently, we screened title and abstract of 48 manuscripts, excluding 32. Eight articles were additionally excluded after reading the full text and verifying that they did not meet the inclusion criteria.

To analyze the quality of the selected studies, the PEDro Scale [45] was applied, and the results are described in Table 1 . The average methodological quality score was $56.06 \%$. Logically, substantial differences were found between the experimental studies scores [46,47] and quasi-experimental studies' scores [48-51]. Two studies [46,47] reached a score between $70 \%$ and $100 \%$, two studies $[48,50]$ were between $50 \%$ and $70 \%$, and the two studies $[49,51]$ that could not count on a control group could not reach the $50 \%$. The blinding condition of the studies requested in items 5 and 6 was not accomplish for any of the studies. All of the studies are educational investigations with students (subjects) and teachers (therapists) and that makes this condition impossible. In addition, just one study [47] achieved item number 8 because the dropouts or exclusion rate was high in most of the studies or was not reported. Item 1 was the category where the highest quality of the study was found because all of the studies specified the eligibility criteria of their sample. 


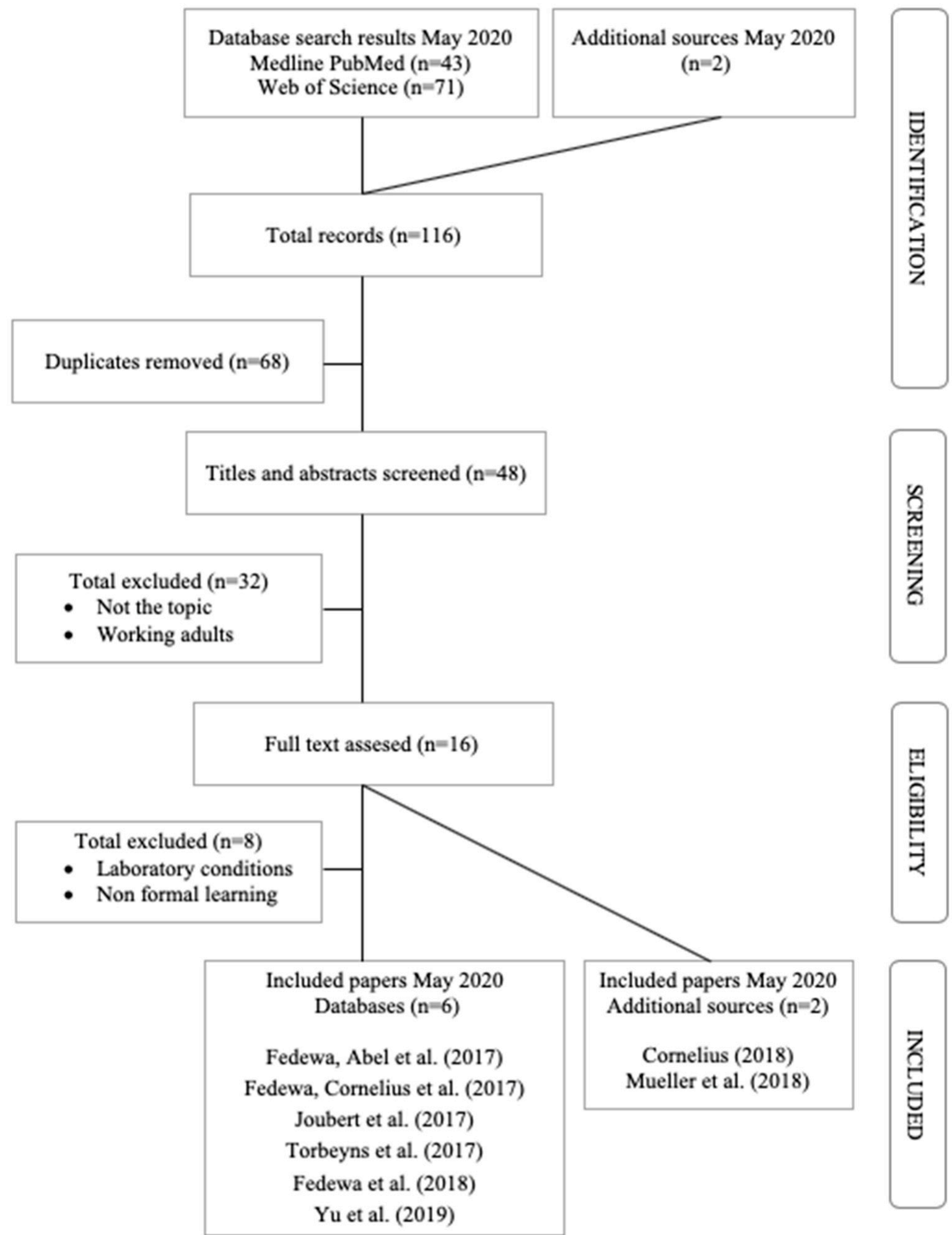

Figure 2. Flow diagram of the search strategy and selection process. 
Table 1. Quality of the included studies.

\begin{tabular}{|c|c|c|c|c|c|c|c|c|c|c|c|c|}
\hline Author (Year) & 1 & 2 & 3 & 4 & 5 & 6 & 7 & 8 & 9 & 10 & 11 & Score \\
\hline Torbeyns et al. (2017) [46] & $\checkmark$ & $\checkmark$ & $\checkmark$ & $\checkmark$ & $\mathrm{x}$ & $x$ & $\checkmark$ & $x$ & $\checkmark$ & $\checkmark$ & $\checkmark$ & 8 \\
\hline Fedewa, Abel et al. (2017) [50] & $\checkmark$ & $\checkmark$ & $\checkmark$ & $x$ & $x$ & $x$ & $\checkmark$ & $x$ & $\checkmark$ & $\checkmark$ & $\checkmark$ & 7 \\
\hline Fedewa, Cornelius et al. (2017) [49] & $\checkmark$ & $\mathrm{x}$ & $x$ & $\checkmark$ & $x$ & $x$ & $x$ & $x$ & $\checkmark$ & $x$ & $\mathrm{x}$ & 3 \\
\hline Joubert et al. (2017) [47] & $\checkmark$ & $\checkmark$ & $\checkmark$ & $\checkmark$ & $x$ & $\mathrm{x}$ & $\checkmark$ & $\checkmark$ & $\checkmark$ & $\checkmark$ & $\checkmark$ & 9 \\
\hline Fedewa et al. (2018) [51] & $\checkmark$ & $x$ & $x$ & $\checkmark$ & $x$ & $x$ & $x$ & $x$ & $\checkmark$ & $\mathrm{x}$ & $x$ & 3 \\
\hline Cornelius (2018) [48] & $\checkmark$ & $\checkmark$ & $\checkmark$ & $x$ & $x$ & $\mathrm{x}$ & $\checkmark$ & $x$ & $\checkmark$ & $\checkmark$ & $\checkmark$ & 7 \\
\hline
\end{tabular}

Note: $\checkmark=$ yes; $x=$ no, non-applicable or insufficiently described. The quality of Mueller, et al. (2017) [52] and Yu et al. (2019) [53] couldn't be analyzed on account of their non-experimental design. Note: PEDro Scale ítems [45]: 1: eligibility criteria specified; 2: random allocation; 3: concealed allocation; 4: groups similar at baseline; 5: subject blinding; 6: therapists blinding; 7: assessor blinding; 8: less than 15\% dropouts; 9: intention-to-treat analysis; 10: between-group statistical com-parisons; 11: point measurements and variability data.

A total of eight manuscripts were considered eligible for this systematic review. Table 2 describes all included studies about bike desks in formal education. The use of bike desks in the classroom is recent because all the studies were published the last four years, between 2017 and 2019. Most of them were conducted in the United States, followed by one each in Belgium [46] and Canada [52]. Half of the papers [46-48,50] compare an intervention group with a control group. Two studies [46,47] are experimental designs with randomized controlled trials. Another two studies [48,50] are quasi-experimental designs with a true control group, two more studies $[49,51]$ are a pre-post intervention testing baseline and the last two papers $[52,53]$ are descriptive studies. Most of the studies' samples $(n=7)$ are students and there is only one study that surveys teachers [52]. The sample sizes are diverse, the smallest [50] gathers 17 students and the largest [48] includes 114 participants. Experimental and quasi-experimental interventions with student sample, have a mean of 52.83 students. Most of the research $(n=6)$ is based on high school students, and just one paper includes undergraduates [47] and it must be considered that one is carried out with special education high school students [51]. The intervention duration of all the studies that comprise students is less than a four-month period: intervention timelines ranged from 60 days to four months. In many of the studies, students had access to bike desks in certain lessons a week for a specified period and in just two studies the time access was flexible $[50,51]$.

Table 2. Included studies.

\begin{tabular}{|c|c|c|c|c|c|}
\hline $\begin{array}{l}\text { Author, } \\
\text { Year }\end{array}$ & $\begin{array}{l}\text { Setting } \\
\text { Sample }\end{array}$ & Duration & $\begin{array}{c}\text { Outcomes } \\
\text { Measurements }\end{array}$ & Instruments & Main Results \\
\hline $\begin{array}{l}\text { Torbeyns et al. } \\
\text { (2017) [46] }\end{array}$ & $\begin{array}{c}\text { Belgium } \\
\text { High School } \\
n=44 \text { students } \\
14.3 \pm 0.6 \text { years } \\
47.7 \% \text { males }\end{array}$ & $\begin{array}{c}15 \text { weeks } \\
4 \times 50 \text { min per } \\
\text { week }\end{array}$ & $\begin{array}{l}\text { Physical activity } \\
\text { Anthropometric } \\
\text { Aerobic fitness } \\
\text { Academic and } \\
\text { cognitive } \\
\text { performance. } \\
\text { Brain function }\end{array}$ & $\begin{array}{c}\text { Accelerometer } \\
\text { PAQ-A } \\
\text { Body analyzer } \\
20 \text { m shuttle run } \\
\text { RAVLT } \\
\text { RCPT } \\
\text { Stroop test } \\
\text { EEG }\end{array}$ & $\begin{array}{c}\text { } \text { Energy } \\
\text { expenditure } \\
\text { BMI changes } \\
\text { † Aerobic fitness } \\
\text { No significant } \\
\text { differences }\end{array}$ \\
\hline $\begin{array}{l}\text { Fedewa, Abel et al. } \\
\text { (2017) [50] }\end{array}$ & $\begin{array}{c}\text { US } \\
\text { High School } \\
n=17 \text { students } \\
14-18 \text { years }\end{array}$ & $\begin{array}{l}60 \text { days. } \\
\text { Flexible access to } \\
\text { bike desks }\end{array}$ & $\begin{array}{c}\text { Feasibility } \\
\text { Physical activity }\end{array}$ & $\begin{array}{c}\text { Interview } \\
\text { Questionnaire } \\
\text { Accelerometer } \\
\text { Student log }\end{array}$ & $\begin{array}{c}\text { More advantages } \\
\text { than limitations } \\
\downarrow \text { Sedentary time } \\
\text { MVPA }\end{array}$ \\
\hline
\end{tabular}


Table 2. Cont.

\begin{tabular}{|c|c|c|c|c|c|}
\hline $\begin{array}{l}\text { Author, } \\
\text { Year }\end{array}$ & $\begin{array}{l}\text { Setting } \\
\text { Sample }\end{array}$ & Duration & $\begin{array}{c}\text { Outcomes } \\
\text { Measurements }\end{array}$ & Instruments & Main results \\
\hline $\begin{array}{l}\text { Fedewa, Cornelius } \\
\text { et al. (2017) [49] }\end{array}$ & $\begin{array}{c}\text { US } \\
\text { High School } \\
n=80 \text { students } \\
16.06 \text { years } 53 \% \\
\text { males }\end{array}$ & $\begin{array}{l}4 \text { months } \\
5 \times 20 \text { min per } \\
\text { week }\end{array}$ & $\begin{array}{c}\text { Feasibility } \\
\text { Physical activity } \\
\text { Behavior }\end{array}$ & $\begin{array}{c}\text { Survey } \\
\text { HR monitor } \\
\text { Momentary Time } \\
\text { Sampling }\end{array}$ & $\begin{array}{l}\text { Pros and cons } \\
\text { HR and calorie } \\
\text { expenditure } \\
\text { No effects }\end{array}$ \\
\hline $\begin{array}{c}\text { Joubert et al. (2017) } \\
\text { [47] }\end{array}$ & $\begin{array}{c}\text { US } \\
\text { University } \\
n=21 \text { students } \\
19-24 \text { years } \\
29 \% \text { males }\end{array}$ & $\begin{array}{c}12 \text { weeks } \\
3 \times 50 \text { min per } \\
\text { week }\end{array}$ & $\begin{array}{c}\text { Feasibility } \\
\text { Physical activity } \\
\text { Academic } \\
\text { performance }\end{array}$ & $\begin{array}{c}\text { Survey } \\
\text { Student log } \\
\text { Standardized } \\
\text { rubric Test }\end{array}$ & $\begin{array}{l}\text { Not disruptive. } \\
\uparrow \text { Physical activity } \\
\downarrow \text { Sedentary time. } \\
\text { No significant } \\
\text { differences }\end{array}$ \\
\hline $\begin{array}{l}\text { Fedewa et al. } \\
(2018)[51]\end{array}$ & $\begin{array}{c}\text { US } \\
\text { High School } \\
n=41 \text { students } \\
14.97 \text { years } \\
80 \% \text { males }\end{array}$ & $\begin{array}{c}16 \text { weeks } \\
\text { Flexible access to } \\
\text { bike desks }\end{array}$ & $\begin{array}{c}\text { Acceptability } \\
\text { Physical activity } \\
\text { Behavior }\end{array}$ & $\begin{array}{l}\text { Questionnaire } \\
\text { HR monitor } \\
\text { Student log } \\
\text { Momentary Time } \\
\text { Sampling }\end{array}$ & $\begin{array}{c}\text { Positive } \\
\mathbf{\uparrow} \text { HR and energy } \\
\text { expenditure } \\
\text { No significant } \\
\text { differences }\end{array}$ \\
\hline $\begin{array}{c}\text { Cornelius (2018) } \\
\text { [48] }\end{array}$ & $\begin{array}{c}\text { US } \\
\text { High School } \\
n=114 \text { students } \\
16 \pm 1.25 \text { years } \\
67 \% \text { males }\end{array}$ & $\begin{array}{c}14 \text { weeks } \\
3 \times 50 \text { min per } \\
\text { week }\end{array}$ & $\begin{array}{c}\text { Self-efficacy } \\
\text { Physical activity } \\
\text { On-task behavior }\end{array}$ & $\begin{array}{l}\text { SES \& SEES } \\
\text { HR monitor } \\
\text { PAQ-A and Log } \\
\text { Momentary Time } \\
\text { Sampling }\end{array}$ & $\begin{array}{l}\text { No differences } \\
\text { 个 HR } \\
\text { Light physical } \\
\text { activity } \\
\text { No differences }\end{array}$ \\
\hline $\begin{array}{l}\text { Mueller, et al. } \\
\text { (2017) [52] }\end{array}$ & $\begin{array}{c}\text { Canada } \\
\text { Kinder-Grade12 } \\
n=107 \text { teachers }\end{array}$ & $\begin{array}{l}\text { Sparks Fly } \\
\text { program }\end{array}$ & $\begin{array}{l}\text { Feasibility } \\
\text { Teacher } \\
\text { perceptions }\end{array}$ & Survey & Pros and cons \\
\hline Yu et al. (2019) [53] & $\begin{array}{c}\text { US } \\
\text { High School } \\
n=28 \text { students }\end{array}$ & $\begin{array}{l}3 \text { months (daily } \\
\text { basis) }\end{array}$ & $\begin{array}{c}\text { Feasibility } \\
\text { Physical activity }\end{array}$ & $\begin{array}{l}\text { Student interviews } \\
\text { Student log }\end{array}$ & $\begin{array}{l}\text { Positive attitudes } \\
\text { 个 Physical activity }\end{array}$ \\
\hline
\end{tabular}

Table 3 presents every outcome assessed depending on the study different variables have been examined. Seven out of eight studies examined the effects of bike desks on students' physical activity [46-48,50,51,53]; six studies analyzed the feasibility or acceptability of bike desks [47,49-53]; five studies focused on academic-related outcomes [46-49,51]; and just one focused on brain function [46], anthropometrics [46], aerobic fitness [46] and self-efficacy [48].

Table 3. Outcomes assessed.

\begin{tabular}{ccccccccc}
\hline & {$[46]$} & {$[50]$} & {$[49]$} & {$[47]$} & [51] & [48] & [52] & [53] \\
\hline Physical Activity & $\checkmark$ & $\checkmark$ & $\checkmark$ & $\checkmark$ & $\checkmark$ & $\checkmark$ & - & $\checkmark$ \\
Feasibility and/or & - & $\checkmark$ & $\checkmark$ & $\checkmark$ & $\checkmark$ & - & $\checkmark$ & $\checkmark$ \\
acceptability & $\checkmark$ & - & $\checkmark$ & $\checkmark$ & $\checkmark$ & $\checkmark$ & - & - \\
Academic related & $\checkmark$ & - & - & - & - & - & - & - \\
Brain function & $\checkmark$ & - & - & - & - & - & - & - \\
Anthropometrics & $\checkmark$ & - & - & - & - & - & - & - \\
Aerobic fitness & - & - & - & - & - & $\checkmark$ & - & - \\
Self-efficacy & - &
\end{tabular}




\subsection{Physical Activity}

The main devices to assess physical activity were accelerometers $[46,50]$ and heart rate monitors $[48,49,51]$. These objective methodologies were completed in two studies with the PAQ-A questionnaire $[46,48]$. There were five studies that gathered bike desk screen data about distance, time, speed or calories in student logs $[47,48,50,51,53]$. All the studies found positive outcomes of bike desk use in formal education: higher energy expenditure $[46,49,51]$, less relative time in sedentary activities $[47,50]$, and higher average heart rate $[48,49,51]$. Nevertheless, only two studies considered physical activity intensity. On one side, one study [50] found that there is more MVPA, and on the other side, another study [48] claims that students only engage in light physical activity. Therefore, bike desks seem to help increase physical activity, but further research is needed to discover if that exercise is enough to reach MVPA, the physical activity recommended for children and adolescents.

\subsection{Feasibility and/or Acceptability}

Feasibility and bike desks acceptability were measured with quantitative and qualitative methods. Most of the studies [47,49-52] applied objective questionnaires or surveys, and there were two studies $[50,53]$ that used interviews. The literature has encountered some shortcomings such as the comfort of the bike seat [50] and difficulties riding a bike and engaging in class simultaneously $[49,52]$. However, the analyzed studies show more positive outcomes than limitations, for example, students' motivation and enjoyment of the bike [48-50,53], active learning with academic benefits $[48,52,53]$ or higher awareness of daily physical activity $[47,53]$.

It has to be noted that, depending on the study, bike desks models are different and this could affect the feasibility with scholars. Most of the studies use a bicycle workstation such us FitDesks ${ }^{\circledR}$ (FD Products, Kernersville, NC, USA) [47,49-51], LifeSpan ${ }^{\circledR}$ C3-DT5 (PCE Fitness, Charlotte, NC, USA) [46] or Sparks Fly®(Run For Life Inc., Waterloo, ON, Canada) [52]. Even though other models of bicycle workstations would perhaps be more acceptable in a high school setting [49], and the stationary bike pedals under the traditional desk used in two studies $[48,53]$ could be a better option, one of them was a DeskCycleTM (3D Innovations, Denver, CO, USA).

\subsection{Academic-Related Outcomes}

Academic achievement, cognitive performance, and academic behavior are the main variables employed in the previous literature to assess academic outcomes. There were only two studies that focused their attention on academic achievement and cognitive performance using standardized tests [46,47]. In addition, one study [46] made use of electroencephalography to analyze brain function. Three studies $[48,49,51]$ measured the students' on-task or/and off-task behavior. In all of them, Momentary Time Sampling instrument were used, which is an interval recording strategy that involves observing whether a behavior occurs or does not occur during specified time periods. No significant differences were found in the use of bike desks related to academic achievement, cognitive performance and behavior.

\subsection{Brain Function, Anthropometrics, Aerobic Fitness and Self-Efficacy}

It is difficult to draw clear conclusions about brain function, anthropometrics, aerobic fitness and self-efficacy, since there is just one study published of each of them. No significant differences were found in students' brain function [46] and self-efficacy [48] after pedaling in a bike desk, but it seems that bike desks have positive outcomes regarding student's anthropometric and aerobic fitness [46]. Despite the aforementioned potential, future studies should investigate those variables. 


\section{Discussion}

Classroom-based physical activity is a contemporary strategy to keep students active while they are learning, and active desks are a good way to achieve it. They seem to be a feasible alternative to fight against the unhealthy traditional seating sedentarism in classrooms. Depending on the type of dynamic seating device implemented, the effects are different [34]; standing desks have been deeply studied in formal education and there are systematic reviews about them $[30,54]$.

To our knowledge, this is the first systematic review of bike desks' effects on students' physical activity and academic outcomes. Bike desks' feasibility and acceptability seem positive in formal education, and these conclusions agree with the ones drawn about standing desks in schools [55].

Classroom-based physical activity interventions with other active workstations have been implemented with elementary students previously [56], however, no studies have employed bike desks within school children under 13 years. It is well known their use with children in many international programs such as "Read and Ride" or the "Sparks Fly Program" [52], so it would be appropriate to study the effects of bike desks on this young population.

Overall, the results of this systematic review prove the efficacy of bike desks in several variables: higher energy expenditure, less sedentary time and higher heart rate. Likewise, standing desks in schools are conducive to some positive effects on students' physical activity levels and energy expenditure [57], which leads to less sedentary time [54,58]. Nevertheless, there are different variables analyzed that make the comparison between the included studies difficult (i.e., average calories, cycle time and distance, heart rate, sedentary time, MVPA time). Objective methods such as accelerometers and heart rate monitors seem to be the best options to quantify and evaluate physical activity [59]. Furthermore, the teacher or leader that guides pedaling should give the same indications (i.e., speed, resistance and Borg perceived exertion scale) to participants.

The implementation of cycle workstations has no effects on students' academic-related outcomes (academic performance, cognitive performance and behavior). According to a systematic review [34], most of the studies agree that there are no significant academic differences between students attending lessons on active desks compared to traditional desks, and it disclosed a better on-task and less off-task behavior. Standardized testing to measure academic performance has been used broadly in physical activity interventions with schoolchildren [60]. Momentary Time Sampling and other direct observation methods provide objective information during classroom-based physical activity lessons [18,26].

Some limitations must be considered. Research evidence is limited, and three out of eight of bike desk studies available have been developed for the same main investigator. To be rigorous and to generalize conclusions, subsequent investigations are required to determine the long-term health benefits, and they should include both treatment and control conditions with clear baseline participants characteristics. In addition, physical activity performed with bike desks could change physical activity patterns during leisure time, follow-up investigations should be done to control this variable. Furthermore, novelty effect should be eliminated, and longer term use of active desks should be observed to check adhesion and motivation to these devices. In addition, in future investigations, sex differences could be an important parameter to consider, as well as including in the studies students with attention deficit hyperactivity disorder, low grade students, obese students, inactive students or any other special population.

\section{Conclusions}

Based on the findings of this systematic review, we suggest that, overall, emerging bike desks seem to be feasible and promising on formal education lessons and could impact students' physical activity profile while they are learning, with no detriment on academic performance. Administrations and schools should consider different aspects before implementing kinesthetic devices to achieve classroom-based physical activity, such 
as target population, feasible subjects, bike desk models and brands, impact in health variables and physical activity intensity. Even though its application is viable, it requires commitment from its users and higher economic investment than other strategies such as active recess or active breaks. Future studies are necessary to compare the effects of bike desks on students' anthropometrics, aerobic fitness and self-efficacy and to confirm the health prospective benefits.

Author Contributions: Conceptualization, B.P.-R. and A.L.; methodology, B.P.-R. and A.O.-D.; software, M.Á.R.-T.; validation, M.Á.R.-T., and A.O.-D.; formal analysis, D.B.; investigation, B.P.-R.; resources, B.P.-R.; data curation, M.Á.R.-T. and A.O.-D.; writing-original draft preparation, B.P.R.; writing-review and editing, B.P.-R. and D.B.; visualization, A.L.; supervision, A.L.; project administration, B.P.-R. All authors have read and agreed to the published version of the manuscript.

Funding: This research received no external funding.

Conflicts of Interest: The authors declare no conflict of interest.

\section{References}

1. Guthold, R.; Stevens, G.A.; Riley, L.M.; Bull, F.C. Global trends in insufficient physical activity among adolescents: A pooled analysis of 298 population-based surveys with 1.6 million participants. Lancet Child Adolesc. Health 2020, 4, 23-35. [CrossRef]

2. Guthold, R.; Stevens, G.A.; Riley, L.M.; Bull, F.C. Worldwide trends in insufficient physical activity from 2001 to 2016: A pooled analysis of 358 population-based surveys with 1.9 million participants. Lancet Glob. Health 2018, 6, e1077-e1086. [CrossRef]

3. Kohl, H.W.; Cook, H.D. Educating the Student Body: Taking Physical Activity and Physical Education to School; National Academies Press: Washington, DC, USA, 2013; Available online: http:/ / www.nap.edu/catalog/18314 (accessed on 24 June 2021).

4. Department of Health and Social Care. Childhood Obesity: A Plan for Action, Chapter 2. 2018. Available online: https://assets.publishing.service.gov.uk/government/uploads/system/uploads/attachment_data/file/718903/childhoodobesity-a-plan-for-action-chapter-2.pdf (accessed on 24 June 2021).

5. Kriemler, S.; Meyer, U.; Martin, E.; van Sluijs, E.M.F.; Andersen, L.B.; Martin, B.W. Effect of school-based interventions on physical activity and fitness in children and adolescents: A review of reviews and systematic update. Br. J. Sports Med. 2011, 45, 923-930. [CrossRef] [PubMed]

6. Klakk, H.; Andersen, L.B.; Heidemann, M.; Møller, N.C.; Wedderkopp, N. Six physical education lessons a week can reduce cardiovascular risk in school children aged 6-13 years: A longitudinal study. Scand. J. Public Health 2014, 42, 128-136. [CrossRef] [PubMed]

7. Plotnikoff, R.C.; Costigan, S.A.; Williams, R.L.; Hutchesson, M.J.; Kennedy, S.G.; Robards, S.L.; Allen, J.; Collins, C.E.; Callister, R.; Germov, J. Effectiveness of interventions targeting physical activity, nutrition and healthy weight for university and college students: A systematic review and meta-analysis. Int. J. Behav. Nutr. Phys. Act. 2015, 12, 1-10. [CrossRef]

8. Mayorga-Vega, D.; Martínez-Baena, A.; Viciana, J. Does school physical education really contribute to accelerometer-measured daily physical activity and non sedentary behaviour in high school students? J. Sports Sci. 2018, 36, 1913-1922. [CrossRef]

9. Cronholm, F.; Lindgren, E.; Rosengren, B.E.; Dencker, M.; Karlsson, C.; Karlsson, M.K. Daily School Physical Activity from before to after Puberty Improves Bone Mass and a Musculoskeletal Composite Risk Score for Fracture. Sports 2020, 8, 40. [CrossRef]

10. Fritz, J.; Rosengren, B.E.; Dencker, M.; Karlsson, C.; Karlsson, M.K. A seven-year physical activity intervention for children increased gains in bone mass and muscle strength. Acta Paediatr. 2016, 105, 1216-1224. [CrossRef] [PubMed]

11. Zavala-Crichton, J.P.; Esteban-Cornejo, I.; Solis-Urra, P.; Mora-Gonzalez, J.; Cadenas-Sanchez, C.; Rodriguez-Ayllon, M.; Migueles, J.H.; Molina-Garcia, P.; Verdejo-Roman, J.; Kramer, A.F.; et al. Association of Sedentary Behavior with Brain Structure and Intelligence in Children with Overweight or Obesity: The ActiveBrains Project. J. Clin. Med. 2020, 9, 1101. [CrossRef]

12. Käll, L.B.; Nilsson, M.; Lindén, T. The Impact of a Physical Activity Intervention Program on Academic Achievement in a Swedish Elementary School Setting. J. Sch. Health 2014, 84, 473-480. [CrossRef]

13. European Commission. Physical Education and Sport at School in Europe Eurydice Report; European Commission: Luxembourg, 2013.

14. Shape America-Society of Health and Physical Educators. Shape of the Nation. Status of Physical Education in the USA. NCPPA 2016. Available online: https://www.shapeamerica.org/uploads/pdfs/son/Shape-of-the-Nation-2016_web.pdf (accessed on 24 June 2021). [CrossRef]

15. WHO. Global Recommendations on Physical Activity for Health; WHO: Geneva, Switzerland, 2010.

16. Daly-Smith, A.; Quarmby, T.; Archbold, V.S.; Routen, A.; Morris, J.L.; Gammon, C.; Bartholomew, J.B.; Resaland, G.K.; Llewellyn, B.; Allman, R.; et al. Implementing physically active learning: Future directions for research, policy, and practice. J. Sport Health Sci. 2020, 9, 41-49. [CrossRef] [PubMed]

17. Liu, A.; Hu, X.; Ma, G.; Cui, Z.; Pan, Y.; Chang, S.; Zhao, W.; Chen, C. Evaluation of a classroom-based physical activity promoting programme. Obes. Rev. 2008, 9, 130-134. [CrossRef] 
18. Kibbe, D.L.; Hackett, J.; Hurley, M.; McFarland, A.; Schubert, K.G.; Schultz, A.; Harris, S. Ten Years of TAKE 10!®: Integrating physical activity with academic concepts in elementary school classrooms. Prev. Med. 2011, 52, S43-S50. [CrossRef]

19. Bartholomew, J.B.; Jowers, E.M.; Roberts, G.; Fall, A.-M.; Errisuriz, V.L.; Vaughn, S. Active Learning Increases Children's Physical Activity across Demographic Subgroups. Transl. J. ACSM 2018, 3, 1-9. [CrossRef]

20. Norris, E.; Shelton, N.; Dunsmuir, S.; Duke-Williams, O.; Stamatakis, E. Physically active lessons as physical activity and educational interventions: A systematic review of methods and results. Prev. Med. 2015, 72, 116-125. [CrossRef]

21. Cecchini, J.A.; Carriedo, A. Effects of an Interdisciplinary Approach Integrating Mathematics and Physical Education on Mathematical Learning and Physical Activity Levels. J. Teach. Phys. Educ. 2020, 39, 121-125. [CrossRef]

22. de Greeff, J.W.; Bosker, R.J.; Oosterlaan, J.; Visscher, C.; Hartman, E. Effects of physical activity on executive functions, attention and academic performance in preadolescent children: A meta-analysis. J. Sci. Med. Sport 2018, 21, 501-507. [CrossRef]

23. Reed, J.A.; Einstein, G.; Hahn, E.; Hooker, S.P.; Gross, V.P.; Kravitz, J. Examining the Impact of Integrating Physical Activity on Fluid Intelligence and Academic Performance in an Elementary School Setting: A Preliminary Investigation. J. Phys. Act. Health 2010, 7, 343-351. [CrossRef]

24. Donnelly, J.E.; Lambourne, K. Classroom-based physical activity, cognition, and academic achievement. Prev. Med. 2011, 52, S36-S42. [CrossRef]

25. Singh, A.S.; Saliasi, E.; Berg, V.V.D.; Uijtdewilligen, L.; De Groot, R.H.M.; Jolles, J.; Andersen, L.B.; Bailey, R.; Chang, Y.-K.; Diamond, A.; et al. Effects of physical activity interventions on cognitive and academic performance in children and adolescents: A novel combination of a systematic review and recommendations from an expert panel. Br. J. Sports Med. 2019, 53, 640-647. [CrossRef]

26. Mahar, M.T.; Murphy, S.K.; Rowe, D.A.; Golden, J.; Shields, A.T.; Raedeke, T.D. Effects of a Classroom-Based Program on Physical Activity and On-Task Behavior. Med. Sci. Sport Exerc. 2006, 38, 2086-2094. [CrossRef]

27. Watson, A.; Timperio, A.; Brown, H.; Best, K.; Hesketh, K.D. Effect of classroom-based physical activity interventions on academic and physical activity outcomes: A systematic review and meta-analysis. Int. J. Behav. Nutr. Phys. Act. 2017, 14, 114. [CrossRef]

28. Graf, C.; Koch, B.; Falkowski, G.; Jouck, S.; Christ, H.; Staudenmaier, K.; Tokarski, W.; Gerber, A.; Predel, H.-G.; Dordel, S. School-based prevention: Effects on obesity and physical performance after 4 years. J. Sports Sci. 2008, 26, 987-994. [CrossRef]

29. Bedard, C.; John, L.S.; Bremer, E.; Graham, J.D.; Cairney, J. A systematic review and meta-analysis on the effects of physically active classrooms on educational and enjoyment outcomes in school age children. PLoS ONE 2019, 14, e0218633. [CrossRef]

30. Altenburg, T.M.; Kist-van Holthe, J.; Chinapaw, M.J.M. Effectiveness of intervention strategies exclusively targeting reductions in children's sedentary time: A systematic review of the literature. Int. J. Behav. Nutr. Phys. Act. 2016, 13, 65. [CrossRef]

31. Gardner, H. Frames of Mind: The Theory of Multiple Intelligences; Basic Book: New York, NY, USA, 2011.

32. Torbeyns, T.; Bailey, S.; Bos, I.; Meeusen, R. Active Workstations to Fight Sedentary Behaviour. Sport Med. 2014, 44, 1261-1273. [CrossRef] [PubMed]

33. Josaphat, K.; Kugathasan, T.A.; Reid, R.E.; Begon, M.; Léger, P.; Labonté-Lemoyne, E.; Sénécal, S.; Arvisais, D.; Mathieu, M. Use of Active Workstations in Individuals with Overweight or Obesity: A Systematic Review. Obesity 2019, 27, 362-379. [CrossRef]

34. Rollo, S.; Crutchlow, L.; Nagpal, T.S.; Sui, W.; Prapavessis, H. The effects of classroom-based dynamic seating interventions on academic outcomes in youth: A systematic review. Learn. Environ. Res. 2019, 22, 153-171. [CrossRef]

35. Torbeyns, T.; De Geus, B.; Bailey, S.; De Pauw, K.; Decroix, L.; Van Cutsem, J.; Meeusen, R. Cycling on a Bike Desk Positively Influences Cognitive Performance. PLoS ONE 2016, 11, e0165510. [CrossRef]

36. Baker, R.; Coenen, P.; Howie, E.; Williamson, A.; Straker, L. The musculoskeletal and cognitive effects of under-desk cycling compared to sitting for office workers. Appl. Ergon. 2019, 79, 76-85. [CrossRef]

37. Peterman, J.E.; Morris, K.L.; Kram, R.; Byrnes, W.C. Cardiometabolic Effects of a Workplace Cycling Intervention. J. Phys. Act. Health 2019, 16, 547-555. [CrossRef] [PubMed]

38. Pilcher, J.J.; Morris, D.M.; Bryant, S.A.; Merritt, P.A.; Feigl, H.B. Decreasing Sedentary Behavior: Effects on Academic Performance, Meta-Cognition, and Sleep. Front. Neurosci. 2017, 11, 219. [CrossRef]

39. Tardif, C.B.; Cantin, M.; Sénécal, S.; Léger, P.-M.; Labonte-Lemoyne, É.; Begon, M.; Mathieu, M.-E. Implementation of Active Workstations in University Libraries-A Comparison of Portable Pedal Exercise Machines and Standing Desks. Int. J. Environ. Res. Public Health 2018, 15, 1242. [CrossRef]

40. Pilcher, J.J.; Baker, V.C. Task Performance and Meta-Cognitive Outcomes When Using Activity Workstations and Traditional Desks. Front. Psychol. 2016, 7, 957. [CrossRef]

41. Ruiter, M.; Loyens, S.; Paas, F. The Effects of Cycling on a Desk Bike on Attention, Retention and Mood during a Video Lecture. Appl. Cogn. Psychol. 2017, 31, 593-603. [CrossRef]

42. Ruiter, M.; Eielts, C.; Loyens, S.; Paas, F. Comparing Cognitive Control Performance During Seated Rest and Self-Paced Cycling on a Desk Bike in Preadolescent Children. J. Phys. Act. Health 2019, 16, 533-539. [CrossRef]

43. Moher, D.; Liberati, A.; Tetzlaff, J.; Altman, D.G. Preferred Reporting Items for Systematic Reviews and Meta-Analyses: The PRISMA Statement. PLoS Med. 2009, 6, e1000097. [CrossRef]

44. Methley, A.M.; Campbell, S.; Chew-Graham, C.; McNally, R.; Cheraghi-Sohi, S. PICO, PICOS and SPIDER: A comparison study of specificity and sensitivity in three search tools for qualitative systematic reviews. BMC Health Serv. Res. 2014, 14, 579. [CrossRef]

45. Maher, C.G.; Sherrington, C.; Herbert, R.D.; Moseley, A.M.; Elkins, M. Reliability of the PEDro Scale for Rating Quality of Randomized Controlled Trials. Phys. Ther. 2003, 83, 713-721. [CrossRef] 
46. Torbeyns, T.; De Geus, B.; Bailey, S.; Decroix, L.; Van Cutsem, J.; De Pauw, K.; Meeusen, R. Bike Desks in the Classroom: Energy Expenditure, Physical Health, Cognitive Performance, Brain Functioning, and Academic Performance. J. Phys. Act. Health 2017, 14, 429-439. [CrossRef] [PubMed]

47. Joubert, L.; Kilgas, M.; Riley, A.; Gautam, Y.; Donath, L.; Drum, S. In-Class Cycling to Augment College Student Academic Performance and Reduce Physical Inactivity: Results from an RCT. Int. J. Environ. Res. Public Health 2017, 14, 1343. [CrossRef]

48. Cornelius, C. A Classroom-based Physical Activity Intervention for Adolescents: Is There a Relationship with Self-efficacy, Physical Activity, and On-task Behavior? 2018. Available online: https://uknowledge.uky.edu/edp_etds/77/ (accessed on 24 June 2021).

49. Fedewa, A.; Cornelius, C.; Ahn, S. The use of bicycle workstations to increase physical activity in secondary classrooms. Health Psychol. Rep. 2017, 6, 60-74. [CrossRef]

50. Fedewa, A.; Abel, M.; Erwin, H.E. The effects of using stationary bicycle desks in classrooms on adolescents' physical activity. J. Occup. Ther. Sch. Early Interv. 2017, 10, 78-89. [CrossRef]

51. Fedewa, A.; Cornelius, C.; Whitney, E.; Ahn, S.; Comis, M. The use of bicycle desks to increase physical activity in two special education classrooms. Health Psychol. Rep. 2018, 6, 339-350. [CrossRef]

52. Mueller, J.; Wudarzewsk, A.; Avitzur, Y. Learning in Motion: Teachers' Perspectives on the Impact of Stationary Bike Use in the Classroom. Int. J. Learn. Teach. Educ. Res. 2017, 16, 15-28.

53. Yu, H.; Kulinna, P.H.; Mulhearn, S.C.; Griffo, J.M.; McLeod, C.E. High School Students`’ Perceptions of Using Desk Cycles. Res. Q. Exerc. Sport 2019, 90, A67. [CrossRef]

54. Minges, K.E.; Chao, A.M.; Irwin, M.L.; Owen, N.; Park, C.; Whittemore, R.; Salmon, J. Classroom Standing Desks and Sedentary Behavior: A Systematic Review. Pediatrics 2016, 137, e20153087. [CrossRef]

55. Hinckson, E.A.; Aminian, S.; Ikeda, E.; Stewart, T.; Oliver, M.; Duncan, S.; Schofield, G. Acceptability of standing workstations in elementary schools: A pilot study. Prev. Med. 2013, 56, 82-85. [CrossRef]

56. Sherry, A.P.; Pearson, N.; Clemes, S.A. The effects of standing desks within the school classroom: A systematic review. Prev. Med. Rep. 2016, 3, 338-347. [CrossRef]

57. Blake, J.J.; Benden, M.E.; Wendel, M.L. Using Stand/Sit Workstations in Classrooms. J. Public Health Manag. Pract. 2012, 18, 412-415. [CrossRef] [PubMed]

58. Clemes, S.A.; Barber, S.E.; Bingham, D.D.; Ridgers, N.; Fletcher, E.L.; Pearson, N.; Salmon, J.; Dunstan, D.W. Reducing children's classroom sitting time using sit-to-stand desks: Findings from pilot studies in UK and Australian primary schools. J. Public Health 2016, 38, 526-533. [CrossRef]

59. Reilly, J.J.; Penpraze, V.; Hislop, J.; Davies, G.; Grant, S.; Paton, J.Y. Objective measurement of physical activity and sedentary behaviour: Review with new data. Arch Dis Child. 2008, 93, 614-619. [CrossRef]

60. Resaland, G.K.; Aadland, E.; Moe, V.F.; Aadland, K.N.; Skrede, T.; Stavnsbo, M.; Suominen, L.; Steene-Johannessen, J.; Glosvik, Ø.; Andersen, J.R.; et al. Effects of physical activity on schoolchildren's academic performance: The Active Smarter Kids (ASK) cluster-randomized controlled trial. Prev. Med. 2016, 91, 322-328. [CrossRef] 